\title{
PEMBINAAN KEPARIWISATAAN MELALUI PENDIDIKAN DAN PELATIHAN BAHASA JEPANG BAGI PENGELOLA DAN GUIDE LOKAL DI DESA WISATA BEDULU KABUPATEN GIANYAR BALI
}

\author{
I.M. Sendra ${ }^{1}$, N.M.S. Wijaya ${ }^{2}$, S. Nugroho $^{3}$, Y. Kristianto ${ }^{4}$, dan N.K. Arismayanti ${ }^{5}$
}

\begin{abstract}
ABSTRAK
Desa Bedulu merupakan salah satu desa di Kecamatan Blahbatuh, Kabupaten Gianyar Bali yang memiliki potensi wisata berupa daya tarik wisata Yeh Pulu dan Goa Gajah. Kesiapan Sumber Daya Manusia merupakan modal dasar keterlibatan masyarakat lokal dalam berbagai aktifitas pariwisata. Berdasarkan karakteristik wisatawan, wisatawan yang datang berkunjung ke Kabupaten Gianyar didominasi oleh Wisatawan Jepang. Tujuan kegiatan ini untuk memberikan pembinaan kepariwisataan melalui pendidikan dan pelatihan Bahasa Jepang bagi pengelola dan pemandu wisata (guide) lokal di Desa Wisata Bedulu sebagai antisipasi menghadapi perkembangan pariwisata daerah tersebut dan perdagangan bebas dunia. Pelaksanaan kegiatan dilakukan di banjar lingkungan Desa Wisata Bedulu, Kabupaten Gianyar Bali. Kegiatan pengabdian kepada masyarakat ini dilakukan dengan cara memberikan pembinaan kepariwisataan berupa pendidikan dan pelatihan yang meliputi: ceramah pariwisata untuk meningkatkan kapasitas masyarakat, praktek langsung Bahasa Jepang yang sangat berguna dan tepat guna kepada masyarakat pengelola dan pemandu wisata (guide) lokal yang ada di Desa Bedulu, Kabupaten Gianyar Bali. Setelah kegiatan ceramah pendidikan dan pelatihan dilaksanakan kemudian dilakukan diskusi dan tanya jawab terkait topik yang dibahas. Pada akhir kegiatan ini diharapkan masyarakat paham dan memiliki pengetahuan dan ketrampilan yang cukup dalam hal pariwisata dan Bahasa Jepang yang berguna untuk profesi yang digelutinya.
\end{abstract}

Kata Kunci : Pendidikan dan Pelatihan, Bahasa Jepang, Pengelola, Guide Lokal, Desa Wisata.

\begin{abstract}
Bedulu Village is a village in Blahbatuh, Gianyar Bali which have tourism potential form of tourist attraction Yeh Pulu and Goa Gajah. Readiness Human Resources is the basis of local community involvement in various tourism activities. Based on the characteristics of travelers, tourists who come to visit the Gianyar regency is dominated by Travellers Japanese. The purpose of this activity to provide tourism development through education and training of Japanese language for managers and tourist guides Local Tourism Village Bedulu as to anticipate the development of tourism in the region and the world free trade. Implementation of the activities carried out in banjar Tourism Village neighborhood Bedulu, Gianyar Bali. Community service activities is done by providing guidance of tourism in the form of education and training that includes lectures tourism to increase the capacity of communities, the practice of direct Japanese language is very useful and appropriate to the community managers and tourist guides locally in the village Bedulu, Gianyar Bali. After the lecture the education and training activities carried out later discussion and questions and answers related to the topics covered. At the end of this activity is expected that people understand and have the knowledge and skills sufficient in terms of tourism and the Japanese language which is useful for the profession that they do.
\end{abstract}

Keywords : Education and Training, Japanese Language, business, Local Guide, Tourism Village.

\footnotetext{
${ }^{1}$ sendramade65@gmail.com; ${ }^{2}$ mdsofiawij@hotmail.com; ${ }^{3}$ snug1976@gmail.com; ${ }^{4}$ inselbali@yahoo.com; ${ }^{5}$ arismayanti_pariwisata@unud.ac.id Staf Pengajar Fakultas Pariwisata, Universitas Udayana
} 


\section{PENDAHULUAN}

Desa Bedulu merupakan salah satu desa di Kecamatan Blahbatuh, Kabupaten Gianyar Bali. Desa Bedulu berada ditengah-tengah Pulau Bali dan memiliki akses yang sangat strategis karena mudah dicapai dari kota propinsi, kabupaten, maupun kota kecamatan. Desa Bedulu terletak membujur dari barat ke timur dan masing-masing sisi barat dan timurnya dibatasi dan diapit oleh dua sungai besar, yaitu Sungai Petanu dan Sungai Pakerisan. Sedangkan ditengah-tengahnya mengalir sungai kecil dan anak sungai, yaitu Tukad Jurang dan Tukad Batuh. Desa Bedulu berbatasan dengan Desa Pejeng, Desa Bitera, Desa Pejeng Kelod, Desa Buruan, dan Desa Kemenuh.

Desa Bedulu memiliki potensi wisata berupa daya tarik wisata Yeh Pulu dan Goa Gajah yang dapat menjadi daya tarik utama bagi wisatawan untuk datang berkunjung. Selain potensi alamnya, Desa Bedulu juga memiliki potensi budaya terkait sejarah Desa Bedulu yang terdapat pada kitab Negara Kertagama yang ditulis oleh Mpu Prapanca pada tahun 1365 Masehi. "Bedulu" berasal dari kata "Badahulu" yang berarti "tempat pemimpin, penghulu atau raja". Badahulu merupakan istana dari raja Bali Kuno terakhir bernama Astasura Ratna Bhumi Banten yang kemudian ditundukkan oleh Majapahit dalam serangan dibawah pimpinan Gajah Mada pada tahun 1343 Masehi.

Pengembangan pariwisata desa-desa di Kabupaten Gianyar tentu berkaitan erat dengan pembangunan perekonomian Kabupaten Gianyar umumnya dan masyarakat Desa Bedulu khususnya, sehingga keterlibatan masyarakat setempat sangat penting dalam proses pengembangan destinasi wisata maupun daya tarik wisata. Dengan berkembangnya pariwisata pada suatu daerah, dari segi ekonomi, dapat memberikan dampak positif bagi daerah tersebut melalui meningkatkan pendapatan masyarakat, menciptakan lapangan pekerjaan yang cukup luas bagi masyarakat setempat dan sekitarnya. Dalam pengembangan pariwisata, hal yang sangat penting untuk terus dibina adalah komunikasi dan pemahaman tentang karakteristik wisatawan yang berkunjung. Dengan adanya wisatawan yang mengunjungi daerah tersebut secara tidak langsung akan muncul permintaan baru dan memperluas segmen pasar akan hasil-hasil pertanian maupun kerajinan tangan serta membuka peluang munculnya lembaga pendidikan yang dapat menghasilkan Sumber Daya Manusia berkualitas di bidang pariwisata.

Hal ini tentu berimplikasi pada kesiapan Sumber Daya Manusia di Desa Bedulu untuk dapat memahami karakteristik Wisatawan Jepang maupun penguasaan Bahasa Jepang. Dengan memiliki kemampuan berkomunikasi dengan wisatawan, maka kita dapat mengetahui kebutuhan dan keinginan wisatawan tersebut serta meminimalisir kesalahpahaman yang mungkin timbul antara host (tuan rumah) dan guest (wisatawan). Hal ini sangat penting dilakukan dalam memberikan pembinaan kepariwisataan melalui pendidikan dan pelatihan Bahasa Jepang khususnya bagi pengelola maupun pemandu wisata (guide) lokal yang terdapat di Desa Bedulu, Kabupaten Gianyar Bali.

"Bagaimanakah mempersiapkan pengelola dan pemandu wisata (guide) lokal di Desa Wisata Bedulu agar dapat memahami karakter dan budaya wisatawan serta agar memiliki kemampuan berkomunikasi dalam Bahasa Jepang dengan Wisatawan Jepang yang berkunjung ke desanya?"

Tujuan dari kegiatan ini adalah untuk memberikan pembinaan kepariwisataan melalui pendidikan dan pelatihan Bahasa Jepang bagi pengelola dan pemandu wisata (guide) lokal di Desa Wisata Bedulu sebagai antisipasi menghadapi perkembangan pariwisata daerah tersebut dan perdagangan bebas dunia. Pelaksanaan kegiatan dilakukan di banjar lingkungan Desa Wisata Bedulu, Kabupaten Gianyar Bali.

Dengan dilaksanakannya kegiatan pengabdian kepada masyarakat dengan judul pembinaan kepariwisataan melalui pendidikan dan pelatihan Bahasa Jepang bagi pengelola dan pemandu wisata (guide) lokal di Desa Wisata Bedulu ini, diharapkan masyarakat yang disasar dalam kegiatan ini mampu memahami pentingnya pengetahuan kepariwisataan, khususnya Bahasa 
Jepang. Peserta diharapkan mampu mengaplikasikan ilmu yang diperoleh dalam kegiatan pengabdian ini dalam hal pengelolaan maupun pemanduan, serta mampu berkomunikasi secara aktif dengan wisatawan mancanegara, khususnya Wisatawan Jepang yang datang ke daerahnya.

Dalam pelaksanaan kegiatan pengabdian ini, kegiatan yang dilakukan untuk pemecahan permasalahan adalah: memberikan ceramah mengenai pariwisata serta pendidikan dan pelatihan praktis Bahasa Jepang bagi pengelola dan pemandu wisata (guide) lokal di Desa Bedulu, Kabupaten Gianyar Bali.

\section{METODE PELAKSANAAN}

Kegiatan pengabdian kepada masyarakat ini dilakukan dengan cara memberikan pembinaan kepariwisataan berupa pendidikan dan pelatihan yang meliputi: ceramah pariwisata untuk meningkatkan kapasitas masyarakat, praktek langsung Bahasa Jepang yang sangat berguna dan tepat guna kepada masyarakat pengelola dan pemandu wisata (guide) lokal yang ada di Desa Bedulu, Kabupaten Gianyar Bali. Setelah kegiatan ceramah pendidikan dan pelatihan dilaksanakan kemudian dilakukan diskusi dan tanya jawab terkait topik yang dibahas. Pada akhir kegiatan ini diharapkan masyarakat paham dan memiliki pengetahuan dan ketrampilan yang cukup dalam hal pariwisata dan Bahasa Jepang yang berguna untuk profesi yang digelutinya.

Khalayak sasaran yang akan dilibatkan dalam kegiatan ini adalah sekitar 30 orang peserta yang terdiri atas masyarakat yang menjadi pengelola dan pemandu wisata (guide) lokal yang ada di Desa Bedulu. Khalayak diberikan ceramah mengenai kepariwisataan serta pendidikan dan pelatihan praktis Bahasa Jepang oleh narasumber yang berkompeten dan ahli dibidang pariwisata dan Bahasa Jepang.

\section{HASIL DAN PEMBAHASAN}

\subsection{Kegiatan Pengabdian Kepada Masyarakat}

Pelaksanaan kegiatan pengabdian masyarakat bagi pengelola dan guide lokal di Desa Bedulu yang diadakan pada tanggal 11 Agustus 2016 dapat dikatakan berhasil karena indikator sasaran dan tujuan yang diharapkan dapat tercapai. Hal ini dapat terlihat dari kehadiran peserta penyuluhan dan pelatihan tepat waktu dan sesuai dengan undangan. Selain itu dapat terlihat dari antusias para pengelola dan guide lokal di Desa Bedulu dalam menerima kedatangan tim pengabdian (tim penyuluh) dan khalayak sasaran siap untuk menerima informasi untuk meningkatkan pengetahuan dan keterampilan berbahasa Jepang yang dianggap berguna sebagai bekal untuk memberikan informasi serta pelayanan kepada wisatawan yang berkunjung ke tempat ini.

Dalam pelatihan dan simulasi ini para pengelola daya tarik wisata dan guide lokal diberikan pemantapan penggunaan Bahasa Jepang yang sudah sering diucapkan dalam melayani tamu dalam kontek penggunaan bahasa yang sopan dan ramah yang sudah menjadi standar internasional. Para peserta pelatihan merasa senang menerima pelatihan ini, namun terdapat beberapa kesulitan dalam mengingat dan mengucapkan Bahasa Jepang, sehingga pada pelatihan ini pemberi materi menyampaikan beberapa kata penting dan memberikan materi yang dapat dibawa pulang, agar peserta memahami dan mempelajari lebih lanjut materi yang diberikan dengan pemilihan bahasa yang digunakan kedengarannya lebih sopan.

Pada pelatihan dan simulasi ini sudah beberapa vocabulary yang terserap oleh peserta pelatihan, walaupun dari penulisan masih sedikit mengalami kesalahan, namun yang terpenting adalah 158 | BULETIN UDAYANA MENGABDI 
mereka sudah mampu mengucapkan dan mempergunakannya dalam melayani wisatawan. Berikut beberapa istilah bahasa Jepang / kata-kata Jepang yang sering diucapkan dalam melayani wisatawan adalah sebagai berikut:

\subsection{Materi Pendidikan dan Pelatihan Bahasa Jepang}

Salam (Aisatsu) Dan Ungkapan (Hyougen)

1) Cara-cara memberikan salam sesuai dengan kebiasaan dan tradisi orang Jepang

\begin{tabular}{|l|l|}
\hline Ungkapan & Makna. \\
\hline 1.Ohayoo gozaimasu & Selamat pagi. \\
\hline 2.Konnichiwa. & Selamat siang/sore. \\
\hline 3. Konbanwa. & Selamat malam. \\
\hline 4. Oyasuminasai. & Selamat beristirahat. \\
\hline 5. Sayonara. & Selamat tinggal/selamat jalan. \\
\hline 6. (Dewa/jaa) mata ashita. & Sampai besok. \\
\hline 7. Arigatoo Gozaimasu. & Terimakasih. \\
\hline 8. Iie, doo itashimashite/kochira koso. & Terimakasih kembali/sama-sama. \\
\hline 9. Sumimasen. & Maaf. (berbuat kekeliruan/kesalahan) \\
\hline 10. (Chotto) sumimasen. & $\begin{array}{l}\text { Permisi (pada waktu akan menanyakan } \\
\text { sesuatu). }\end{array}$ \\
\hline 11. Shitsurei-shimasu (itashimasu) & $\begin{array}{l}\text { Permisi (pada waktu anda mengganggu } \\
\text { seseorang) }\end{array}$ \\
\hline 12.O-saki ni shitsurei shimasu (itashima- & $\begin{array}{l}\text { Permisi, saya duluan (pada waktu anda } \\
\text { permisi duluan). }\end{array}$ \\
\hline su). & Tolong tunggu sebentar. \\
\hline 13. Chotto matte kudasai. & Selamat (atas kesuksesan seseorang) \\
\hline 14. Omedetoo gozaimasu. & Apa kabar. \\
\hline 15.O-genki desu ka. & Berkat doa anda saya sehat-sehat saja. \\
\hline 16. Okage-sama de genki desu. &
\end{tabular}

2) Cara-cara memperkenalkan diri (jiko shoukai) dengan menyebutkan nama dan tempat bekerja

\begin{tabular}{|l|l|}
\hline 1.Hajimemashite. & (Perkenalkan) \\
\hline $\begin{array}{l}\text { 2 Watashi no namae wa .........desu. } \\
\text { Watashi no namae wa Arya desu }\end{array}$ & Nama saya adalah Arya. \\
\hline 3.Douzo yoroshiku. & (Senang berkenalan dengan anda) \\
\hline
\end{tabular}

3) Ungkapan-ungkapan hormat pada waktu memberikan pelayanan kepada wisatawan.

\begin{tabular}{|l|l|l|}
\hline 1. Irasshaimase. & Selamat datang & Pada waktu tamu baru datang. \\
\hline $\begin{array}{l}\text { 2. Doomo arigatoo gozaima- } \\
\text { Su. } \\
\text { Doomo arigatoo gozaima- } \\
\text { Shita. }\end{array}$ & Terimakasih banyak. & $\begin{array}{l}\text { Pada waktu anda meneri- } \\
\text { ma bantuan/sesuatu. }\end{array}$ \\
\hline $\begin{array}{l}\text { 3. Hai, wakarimashita } \\
\text { 4. Chotto matte kudasai }\end{array}$ & Baiklah. & $\begin{array}{l}\text { Pada waktu anda mengerti apa } \\
\text { yang diinginkan atau } \\
\text { diinstruksikan oleh tamu }\end{array}$ \\
\hline
\end{tabular}


Pembinaan Kepariwisataan Melalui Pendidikan dan Pelatihan Bahasa Jepang Bagi Pengelola dan Guide Lokal di Desa Wisata Bedulu Kabupaten Gianyar Bali

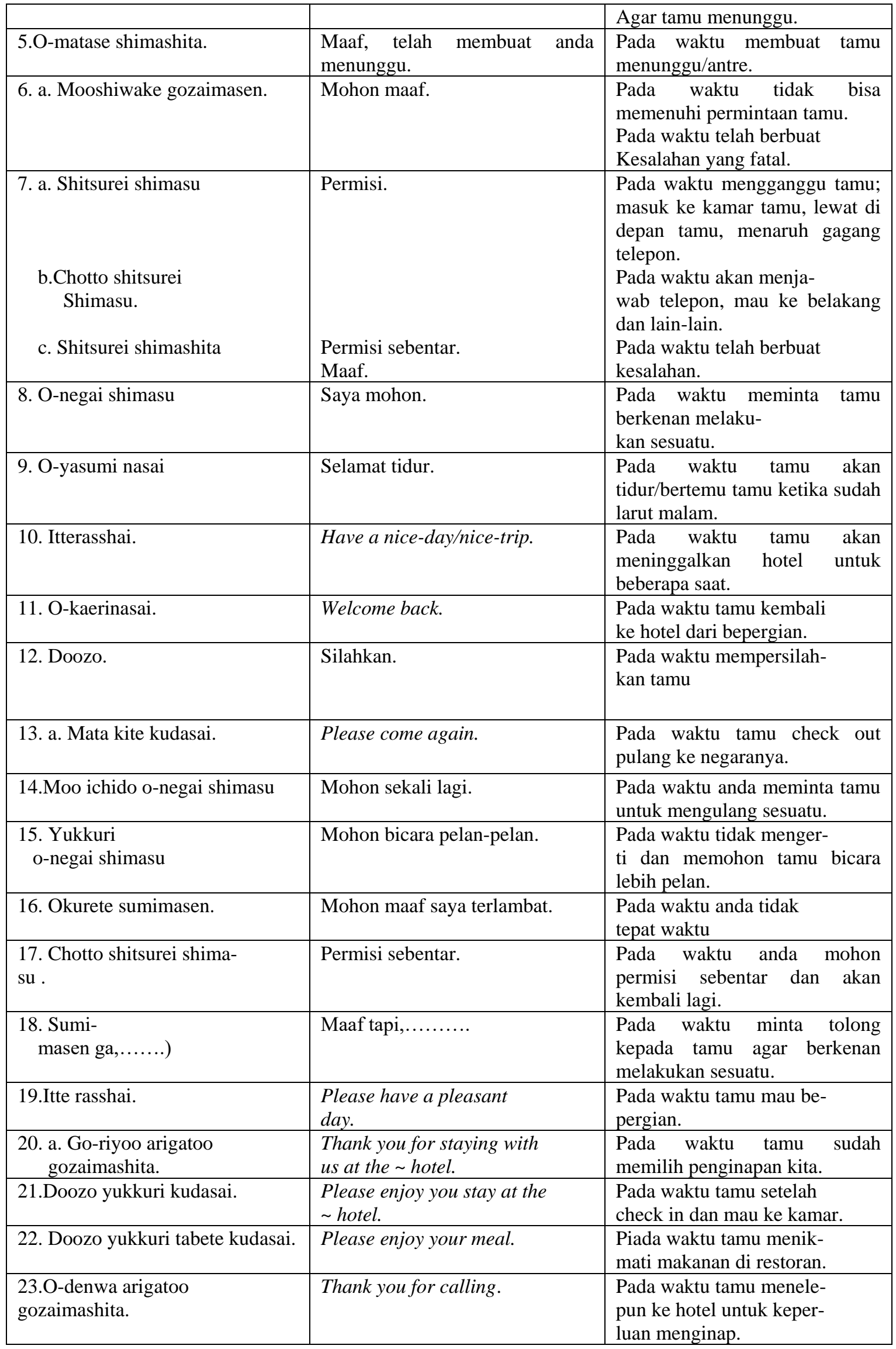




\begin{tabular}{|l|l|l|}
\hline $\begin{array}{l}\text { 24.Go-yoyaku arigatoo } \\
\text { gozaimashita. }\end{array}$ & Thank you for your reservation. & $\begin{array}{l}\text { Pada waktu tamu telah } \\
\text { melakukan reservation. }\end{array}$ \\
\hline 25. Gomen kudasai. & $\begin{array}{l}\text { Excuse me, any body in the } \\
\text { room? }\end{array}$ & $\begin{array}{l}\text { Pada waktu mau masuk } \\
\text { ke kamar tamu dengan cara } \\
\text { mengetuk pintu ter- } \\
\text { lebih dahulu; setelah di- } \\
\text { persilakan masuk ucap- } \\
\text { kan shitsurei shimasu. }\end{array}$ \\
\hline 26.O-kyaku-san/ O-kyaku-sama & Miss;Mr;Ms. & $\begin{array}{l}\text { Pada waktu memanggil tamu; } \\
\text { kalau tahu nama- } \\
\text { nya lebih baik panggil namanya } \\
\text { (nama keluarga) }\end{array}$ \\
\hline
\end{tabular}

4) Ungkapan (hyoogen) sesuai dengan tingkat kesopanannya.

\begin{tabular}{|l|l|l|}
\hline \multicolumn{1}{|c|}{ Bentuk Sopan } & \multicolumn{1}{c|}{ Bentuk Hormat } & \multicolumn{1}{c|}{ Arti } \\
\hline 1. Irasshaimase & Irasshainasaimase & Selamat Datang \\
\hline 2. Doomo arigatoo & Doomo arigatoo gozaimasu & Terima kasih banyak \\
\hline 3. Hai, wakarimashita & Hai, kashikomarimashita & Ya, saya sudah mengerti \\
\hline 4. Oyasuminasai & Oyasuminasaimase & Selamat beristirahat \\
\hline 5. Shitsurei shimasu & Shitsurei itashimasu & Maaf/permisi \\
\hline 6. Chooto matte kudasai & Shooshoo o-machi kudasai & Tunggu sebentar \\
\hline 7. Doozo mite kudasai & Doozo goran kudasai & Silakan lihat-lihat \\
\hline 8. Omatase Shimashita & O-matase itashimashita & Maaf membuat menunggu \\
\hline 9. Sumimasen & Moshiwake gozaimasen & Mohon maaf \\
\hline 10. Mata kite kudasai & Mata okoshi kudasai & Silakan datang lagi \\
\hline 11. Okurete sumimasen & $\begin{array}{l}\text { Okurete moshiwake gozai- } \\
\text { Masen }\end{array}$ & Mohon maaf saya terlambat \\
\hline 12. Ii desu ka & Yoroshii desu ka & Bolehkah? \\
\hline 13. Hai, ii desu & Hai, kekko desu. & Ya, oke! \\
\hline 14. Sumimasen ga,......... & Osore irimasu ga,............ & Maaf ........................ \\
\hline 15. Tanaka san desu & Tanaka-sama degozaimasu & Tuan Tanaka \\
\hline
\end{tabular}

5) Cara Menghitung Angka

\begin{tabular}{|c|c|c|c|c|}
\hline Angka & Belasan & Ratusan & Ribuan & Puluhan Ribu \\
\hline 1.Ichi. & 11 juu-ichi & 100 hyaku & 1000 sen & 10.000 ichiman \\
\hline 2.Ni. & 12 juu-ni & 200 nihyaku. & 2000 nisen & 20.000 niman \\
\hline 3.San. & 13 juu-san & 300 sambyaku & 3000 sanzen & 30.000 sanman \\
\hline 4.Yon/Yo/Shi. & 14 juu-yon & 400 yonhyaku & 4000 yonsen & 40.000 yonman \\
\hline 5.Go. & 15 juu-go & 500 gohyaku & 5000 gosen & 50.000 goman \\
\hline 6.Roku. & 16 juu-roku & 600 roppyaku & 6000 rokusen & 60.000 rokuman \\
\hline 7.Nana/Sichi. & 17 juu-nana & 700 nanahyaku & 7000 nanasen & 70.000 nanaman \\
\hline 8.Hachi. & 18juu-hachi & 800 happyaku & 8000 hassen & 80.000 hachiman \\
\hline 9.Ku/Kyuu. & 19juu-kyuu & 900 kyuuhyaku & 9000 kyuusen & 90.000 kyuuman \\
\hline 10.Juu. & 20 ni-juu & 1000 sen & 10.000 ichiman & 100.000 hyakuman \\
\hline
\end{tabular}

6) Latihan Membaca Angka

\begin{tabular}{|l|l|}
\hline 10 Juu & Latihan Baca \\
\hline 100 Hyaku & $345 ; 654 ; 764 ; 876 ; 897 ; 983$ \\
\hline 1000 Sen & $3.567 ; 4.675 ; 8.986 ; 4.768$ \\
\hline
\end{tabular}


Pembinaan Kepariwisataan Melalui Pendidikan dan Pelatihan Bahasa Jepang Bagi Pengelola dan Guide Lokal di Desa Wisata Bedulu Kabupaten Gianyar Bali

\begin{tabular}{|l|l|}
\hline 10.000 Ichi man & $35.675 ; 76.897 ; 76.785 ; 98.939$ \\
\hline 100.000 Ju man & $167.543 ; 345.675 ; 458.879 ; 674.567$. \\
\hline 1000.000 Hyaku man & $1.547 .675 ; 3.687 .98 ; 5.987 .456 ; 6.789 .983$. \\
\hline 10.000 .000$. Sen man & $15.567 .987 ; 36.678 .763 ; 57.945 .136 .87 .978 .654$. \\
\hline 100.000 .000 Ichi oku & $345.675 .897 ; 786.543 .678 ; 985.675 .765 ; 567.765 .897$. \\
\hline 1.000 .000 .000 Juu oku & $3.453 .765 .876 ; 9.654 .453 .984 ; 6.456 .341 .765$. \\
\hline 10.000 .000 .000 Hyaku oku & $45.765 .897 .965 ; 89.654 .678 .895 ; 98.564 .897 .543$. \\
\hline 100.000 .000 .000$. Sen oku & $345.789 .654 .679 ; 789.564 .631 .897 ; 654.768 .987 .453$. \\
\hline
\end{tabular}

7) Pola-Pola Kalimat

\begin{tabular}{|l|l|l|l|}
\hline \multicolumn{1}{|c|}{ Subjek wa } & \multicolumn{1}{c|}{ Predikat (Kt Benda) } & \multicolumn{1}{c|}{ Desu (+) } \\
\hline 1 & $\begin{array}{l}\text { Watashi wa } \\
\text { (Saya) }\end{array}$ & $\begin{array}{l}\text { Ngurah } \\
\text { (Ngurah) }\end{array}$ & $\begin{array}{l}\text { Desu } \\
\text { (Adalah) }\end{array}$ \\
\hline 2 & Subjek wa & Predikat (Kt Benda) & Dewa Arimasen (-) \\
\hline & $\begin{array}{l}\text { Watashi wa } \\
\text { (Saya) }\end{array}$ & $\begin{array}{l}\text { Nihon jin } \\
\text { (Orang Jepang) }\end{array}$ & $\begin{array}{l}\text { Dewa Arimasen } \\
\text { (Bukan) }\end{array}$ \\
\hline 3 & Tanya: Subjek wa & Predikat & Desu ka (?) \\
& $\begin{array}{l}\text { (Anda) } \text { Anata wa } \\
\text { Jawab: Hai, Watashi wa } \\
\text { Ya, Saya } \\
\text { Iie, Watashi } \\
\text { Bukan, Saya }\end{array}$ & $\begin{array}{l}\text { Nihonjin } \\
\text { (Orang Jepang) } \\
\text { Nihon-jin } \\
\text { (Orang Jepang) } \\
\text { Nihon-jin } \\
\text { (Orang Jepang) }\end{array}$ & $\begin{array}{l}\text { Desu ka } \\
\text { (Apakah) } \\
\text { Desu (+) } \\
\text { (Adalah) } \\
\text { Dewa Arimasen } \\
\text { (Bukan) }\end{array}$ \\
\hline
\end{tabular}

Catatan:

wa sebagai penanda pokok kalimat (Subjek). Desu penanda predikat diterjemahkan adalah. Untuk menjadikan kalimat Tanya desu ditambah ka (desu ka) artinya apakah?). Untuk menjadikan bentuk negatif desu diganti dengan dewa arimasen artinya bukan.

8) Kalimat Tanya Dengan Jawaban Alternatif (Pilihan)

\begin{tabular}{|c|c|c|c|}
\hline & Subjek wa & ----------- desu ka & -------- desu ka \\
\hline 1 & $\begin{array}{l}\text { Tanya: Anata wa } \\
\text { Anda } \\
\text { Jawab:Watashi wa } \\
\text { (Saya) } \\
\text { Atau Watashi wa } \\
\quad \text { (Saya) }\end{array}$ & $\begin{array}{l}\text { Indonesia jin desu ka, } \\
\text { (Apakah Orang Indonesia ataukah) } \\
\text { Nihon jin } \\
\text { (Orang Jepang) } \\
\text { Indoneshia-jin } \\
\text { (Orang Indonesia) }\end{array}$ & $\begin{array}{l}\text { Nihon jin desu ka } \\
\text { (Orang Jepang) } \\
\text { Desu } \\
\text { (Adalah) } \\
\text { Desu } \\
\text { (Adalah) }\end{array}$ \\
\hline
\end{tabular}

9) Kalimat Tanya Dengan Kata Penanya

\begin{tabular}{|c|c|c|}
\hline Subjek wa & Kata Penanya & Desu ka \\
\hline $\begin{array}{l}\text { Tanya: Anata wa } \\
\text { (Anda) }\end{array}$ & $\begin{array}{l}\text { Dare } \\
\text { (Siapa) }\end{array}$ & Desu ka \\
\hline $\begin{array}{l}\text { Jawab:Watashi wa } \\
\text { (Saya) }\end{array}$ & $\begin{array}{l}\text { Gaido } \\
\text { (Guide) }\end{array}$ & Desu \\
\hline $\begin{array}{l}\text { Tanya: Anata wa } \\
\text { (Anda) }\end{array}$ & $\begin{array}{l}\text { Nan-sai } \\
\text { (Berapa tahun usianya) }\end{array}$ & \\
\hline $\begin{array}{l}\text { Jawab:Watashi wa } \\
\text { (Saya) }\end{array}$ & $\begin{array}{l}\text { 12-sai } \\
\text { (Berusia } 12 \text { tahun) }\end{array}$ & Desu \\
\hline Tanya: Anata no namae wa & Nan & Desu ka \\
\hline
\end{tabular}




\begin{tabular}{|c|l|l|}
\hline $\begin{array}{l}\text { (Nama anda) } \\
\text { Jawab:Watashi no namae wa } \\
\text { (Nama saya) }\end{array}$ & $\begin{array}{l}\text { (Siapakah) } \\
\text { Ardana } \\
\text { (Ardana) }\end{array}$ & Desu \\
\hline
\end{tabular}

10) Kata Ganti Penunjuk Benda

\begin{tabular}{|c|c|c|c|}
\hline A & 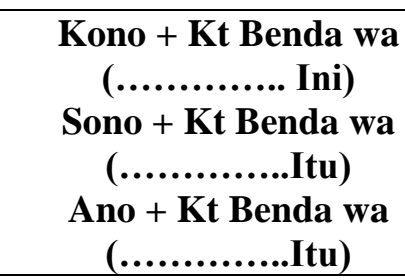 & $\begin{array}{c}\text { Predikat } \\
\text { (Kata Benda) }\end{array}$ & Desu \\
\hline 1 & $\begin{array}{l}\text { Kono Hon wa } \\
\text { (Buku ini) }\end{array}$ & $\begin{array}{l}\text { Watashi no Hon } \\
\text { (Buku milik saya) }\end{array}$ & $\begin{array}{l}\text { Desu } \\
\text { (adalah) }\end{array}$ \\
\hline 2 & $\begin{array}{l}\text { Sono Hon wa } \\
\text { (Buku itu) }\end{array}$ & $\begin{array}{l}\text { Sensei no Hon } \\
\text { (Buku milik Pak Guru) }\end{array}$ & $\begin{array}{l}\text { Desu } \\
\text { (adalah) }\end{array}$ \\
\hline 3 & $\begin{array}{l}\text { Ano Hon wa } \\
\text { (Buku itu) }\end{array}$ & $\begin{array}{l}\text { Anita-san no Hon } \\
\text { (Buku milik Si Anita) }\end{array}$ & $\begin{array}{l}\text { Desu } \\
\text { (adalah) }\end{array}$ \\
\hline 4 & $\begin{array}{l}\text { T: Kono Hon wa } \\
\text { (Buku Ini) } \\
\text { J:Sono Hon wa } \\
\text { (Buku itu) }\end{array}$ & $\begin{array}{l}\text { Dare no Hon } \\
\text { (Buku Milik Siapa?) } \\
\text { Watashi no Hon } \\
\text { (Buku milik saya) } \\
\end{array}$ & $\begin{array}{l}\text { Desu ka } \\
\text { Desu } \\
\text { (Adalah) }\end{array}$ \\
\hline 5 & $\begin{array}{l}\text { T:Sono Kaban wa } \\
\text { (Tas Itu) } \\
\text { J:Kono Kaban wa } \\
\text { (Tas Ini) }\end{array}$ & $\begin{array}{l}\text { Dare no Kaban } \\
\text { (Tas milik Siapa) } \\
\text { Sensei no Kaban } \\
\text { (Tas milik Pak Guru) }\end{array}$ & $\begin{array}{l}\text { Desu ka } \\
\text { Desu }\end{array}$ \\
\hline 6 & $\begin{array}{l}\text { T:Ano Empitsu wa } \\
\text { (Pensil Itu) } \\
\text { J:Ano Empitsu wa } \\
\text { (Pensil Itu) }\end{array}$ & $\begin{array}{l}\text { Dare no Empitsu } \\
\text { (Pensil milik Siapa) } \\
\text { Budi-san no Empitsu } \\
\text { (Pensil milik Si Budi) }\end{array}$ & $\begin{array}{l}\text { Desu ka } \\
\text { Desu }\end{array}$ \\
\hline
\end{tabular}

\begin{tabular}{|c|c|c|c|}
\hline B & $\begin{array}{l}\text { Kore (Ini), Sore } \\
\text { (Itu), Are (Itu) wa }\end{array}$ & Predikat (Kata Benda) & Desu \\
\hline 1 & $\begin{array}{l}\text { Kore wa } \\
\text { (Ini) }\end{array}$ & $\begin{array}{l}\text { Keshoohin } \\
\text { (Kosmetik) }\end{array}$ & $\begin{array}{l}\text { Desu } \\
\text { (Adalah) }\end{array}$ \\
\hline 2 & $\begin{array}{l}\text { Sore wa } \\
\text { (Itu) }\end{array}$ & $\begin{array}{l}\text { Kibori } \\
\text { (Patung) }\end{array}$ & $\begin{array}{l}\text { Desu } \\
\text { (Adalah) }\end{array}$ \\
\hline 3 & $\begin{array}{l}\text { Are wa } \\
\text { (Itu) }\end{array}$ & $\begin{array}{l}\text { Koosui } \\
\text { (Kosmetik) }\end{array}$ & $\begin{array}{l}\text { Desu } \\
\text { (Adalah) }\end{array}$ \\
\hline 4 & $\begin{array}{l}\mathrm{T}: \text { Kore wa } \\
\text { (Ini) } \\
\mathrm{J}: \text { Sore wa } \\
\text { (Itu) }\end{array}$ & $\begin{array}{l}\text { Nan } \\
\text { (Apa) } \\
\text { Kuriimu } \\
\text { (Cream) }\end{array}$ & $\begin{array}{l}\text { Desu ka } \\
\text { Desu } \\
\text { (Adalah) }\end{array}$ \\
\hline 5 & $\begin{array}{l}\text { T: Sore wa } \\
\quad \text { Itu) } \\
\text { J: Kore wa } \\
\text { (Ini) }\end{array}$ & $\begin{array}{l}\text { Nan } \\
\text { (Apa) } \\
\text { Udedokei } \\
\text { (Jam Tangan) }\end{array}$ & $\begin{array}{l}\text { Desu ka } \\
\text { Desu }\end{array}$ \\
\hline 6 & $\begin{array}{l}\text { T:Are wa } \\
\text { (Itu) }\end{array}$ & $\begin{array}{l}\text { Nan } \\
\text { (Apa) }\end{array}$ & Desu ka \\
\hline
\end{tabular}


Pembinaan Kepariwisataan Melalui Pendidikan dan Pelatihan Bahasa Jepang Bagi Pengelola dan Guide Lokal di Desa Wisata Bedulu Kabupaten Gianyar Bali

\begin{tabular}{|l|l|l|l|}
\hline $\begin{array}{l}\text { J:Are wa } \\
\text { (Itu) }\end{array}$ & $\begin{array}{l}\text { Roshoon } \\
\text { (Lotion) }\end{array}$ & Desu \\
\hline
\end{tabular}

Catatan

Kono + KB (Kt Benda) dan Kore dipakai untuk menunjukkan benda yang letaknya dekat dengan pembicara jauh dari lawan berbicara. Sono + KB dan Sore dipakai untuk menunjukkan benda yang letaknya jauh dari pembicara dekat dengan lawan berbicara. Ano + KB dan Are dipakai untuk menunjukkan benda yang letaknya jauh dari kedua belah pihak.

Kalau pertanyaannya Kore maka jawabannya Sore; kalau pertanyaannya Sore maka jawabannya Kore; kalau pertanyaannya Are maka jawabannya Are. Demikian pula kalau pertanyaannya Kono + KB jawabannya Sono + KB; Sono + KB jawabannya Kono + KB, Ano + KB jawabannya Ano + $\mathrm{KB}$.

11) Kata Penanya

Dono (yang mana) Dono + Kt Benda $=\ldots \ldots$...yang mana $?$

Dore (yang mana) Dore tidak diikuti kata benda

Makna Partikel No

\begin{tabular}{|c|c|c|c|c|c|}
\hline $\mathbf{A}$ & Kata Ganti Orang & \multicolumn{2}{|c|}{$\begin{array}{c}\text { No } \\
\text { (Milik) }\end{array}$} & \multicolumn{2}{|c|}{ Kata Benda Desu ka } \\
\hline 1 & $\begin{array}{l}\text { Sensei } \\
\text { (Pak Guru) }\end{array}$ & \multicolumn{2}{|c|}{$\begin{array}{l}\text { No } \\
\text { (Milik) }\end{array}$} & \multicolumn{2}{|c|}{$\begin{array}{l}\text { Koosui desu } \\
\text { (Parfum) }\end{array}$} \\
\hline 2 & $\begin{array}{l}\text { Dare } \\
\text { (Siapa) }\end{array}$ & \multicolumn{2}{|c|}{$\begin{array}{l}\text { No } \\
\text { (Milik) }\end{array}$} & \multicolumn{2}{|c|}{$\begin{array}{l}\text { Koosui Desu ka } \\
\text { (Parfum) }\end{array}$} \\
\hline $\mathrm{B}$ & $\begin{array}{l}\text { Kata Benda } 1 \\
\text { (Menerangkan) }\end{array}$ & \multicolumn{2}{|c|}{$\begin{array}{l}\text { No } \\
\text { (tidak diterjemahkan) }\end{array}$} & \multicolumn{2}{|c|}{ Kata Benda 2 Desu } \\
\hline 1 & $\begin{array}{l}\text { Nihon go } \\
\text { (Bahasa Jepang) }\end{array}$ & \multicolumn{2}{|c|}{ No } & \multicolumn{2}{|c|}{$\begin{array}{l}\text { Hon desu } \\
(\text { Buku) }\end{array}$} \\
\hline 2 & $\begin{array}{l}\text { Nan } \\
\text { (Apa) }\end{array}$ & \multicolumn{2}{|l|}{ No } & \multicolumn{2}{|c|}{$\begin{array}{l}\text { Hon desu ka } \\
\text { (Buku) }\end{array}$} \\
\hline $\mathbf{A}$ & \multicolumn{2}{|c|}{ Subjek wa } & \multicolumn{2}{|c|}{ Dono + Kt Benda } & Desu ka \\
\hline 1 & \multicolumn{2}{|c|}{$\begin{array}{l}\text { T: Anata no megane wa } \\
\text { (Kaca mata anda) } \\
\text { J:Watashi no megane wa } \\
\text { (Kaca mata saya) }\end{array}$} & \multicolumn{2}{|c|}{$\begin{array}{l}\text { Dono megane } \\
\text { (Kaca mata yang mana) } \\
\text { Sono megane } \\
\text { (Kaca mata yang itu) }\end{array}$} & $\begin{array}{l}\text { Desu ka } \\
\text { Desu }\end{array}$ \\
\hline B & \multicolumn{2}{|c|}{ Subjek wa } & \multicolumn{2}{|c|}{ Dore (Yang manakah) } & Desu ka \\
\hline 1 & \multicolumn{2}{|c|}{$\begin{array}{l}\text { T:Anata no T Shatsu wa } \\
\text { (T Shirt milik anda) } \\
\text { J:Watashi no T Shatsu wa } \\
\text { (T Shirt milik saya) }\end{array}$} & \multicolumn{2}{|c|}{$\begin{array}{l}\text { Dore } \\
\text { (yang manakah) } \\
\text { Kore } \\
\text { (Yang ini) }\end{array}$} & $\begin{array}{l}\text { Desu ka } \\
\text { Desu }\end{array}$ \\
\hline
\end{tabular}

12) Daftar Kosa Kata

\begin{tabular}{|l|l|}
\hline Kuwe Bali & Bari no okashi.(バリのお菓子)。 \\
\hline Parfume & Koosui (香水)。 \\
\hline Cosmetic & Keshoohin. (化粧品)。 \\
\hline Cream & Kuriimu. (クリーム)。 \\
\hline Minyak rambut & Pomaado.(パマード)。 \\
\hline Jam tangan & Udedokei.(腕時計)。 \\
\hline
\end{tabular}




\begin{tabular}{|c|c|}
\hline Kaca mata & Megane. (眼鏡) 。 \\
\hline Oil & Oiru （オイル）。 \\
\hline Lotion & Rooshon. (ローション)。 \\
\hline Sunblock & Sanborokku. (サンブロック)。 \\
\hline Gelas hias & Kazari koppu.（飾りコップ）。 \\
\hline Hiasan & Kazarimono.（飾り物）。 \\
\hline Aksesoris & Akusesarii. (アクセサリー)。 \\
\hline Bingkai foto & $\begin{array}{llll}\text { Sashin } & \text { no } & \text { fureemu } & \text { (fuchi) } \\
(\text { 写真のフレーム・縁) } & & \\
\end{array}$ \\
\hline Bingkai gambar & Gakubuchi. (額縁) 。 \\
\hline Celana (pants) & Pantsu (han zubon).(パンツ・半ズボン) \\
\hline Celana panjang & Zubon.(ズボン)。 \\
\hline Pakaian dalama wanita & Jooseiyoo shitagi.（女性用下着）。 \\
\hline Pakaian dalam laki-laki & Danseiyoo shitagi.（男性用下着）。 \\
\hline Pakaian seragam & Seifuku. (制服・ユニフォーム)。 \\
\hline Rok & Sukaato. (スカート)。 \\
\hline Pakaian & Kimono. (着物)。 \\
\hline Bra & Burajaa.（ブラジャー）。 \\
\hline Pakaian renang & Suieifuku （水泳服）。 \\
\hline Topi & Booshi.（帽子）。 \\
\hline Pensil kayu & Ki de tsukutta empitsu.(木で作った鉛筆）。 \\
\hline Sandal. & Sandaru.(サンダル)。 \\
\hline Sepatu & Kutsu.(靴)。 \\
\hline Boneka & Ningyoo. (人形)。 \\
\hline Wayang golek. & $\begin{array}{lrr}\text { Mokusei } & \text { no } & \text { ningyoo. } \\
(\text { (ワヤンゴレックの人形) } & \end{array}$ \\
\hline Vas bunga & Kabin.（花瓶）。 \\
\hline Tas & Kaban.（鞄）。 \\
\hline Tas kulit & Kawa no kaban.(皮の鞄)。 \\
\hline Dompet. & Saifu. (財布)。 \\
\hline Ikat pinggang & Beruto. (ベルト)。 \\
\hline Scarf & Sukaapu. (スカープ)。 \\
\hline Shawl & Shooru. (ショール)。 \\
\hline Sabun & Seken. \\
\hline Aroma terapi oil & Aroma Serapisuto oiru. \\
\hline Lulur & Kiiroi oshiroi.（黄色い白粉）。 \\
\hline Tempat lilin & $\begin{array}{l}\text { Roosoku } \\
\text { (iremono). (蛹燭の器・入れ物) }\end{array}$ \\
\hline Gantungan kunci & Kagi no kazarimono.（鍵の飾り物）。 \\
\hline Bross (pin) & Buroochi (pin).（ブローチ・ピン）。 \\
\hline Pin dasi & Nekutai pin. (ネクタイピン)。 \\
\hline Bando & Bando. (バンド)。 \\
\hline Ikat rambut & Kaminoke no shibaru.（髪の毛の縛る）。 \\
\hline Cincin perak & Ginyubiwa.（銀指輪）。 \\
\hline Cincin emas & Kinyubiwa.（金指輪）。 \\
\hline Kerajinan emas dan perak & Kinginzaiku.（金銀細工）。 \\
\hline
\end{tabular}


Pembinaan Kepariwisataan Melalui Pendidikan dan Pelatihan Bahasa Jepang Bagi Pengelola dan Guide Lokal di Desa Wisata Bedulu Kabupaten Gianyar Bali

\begin{tabular}{|l|l|}
\hline Kutek & Tsume no penki. (爪のペンキ)。 \\
\hline $\begin{array}{l}\text { Gantungan kunci alat kelamin } \\
\text { laki }\end{array}$ & $\begin{array}{l}\text { Otoko doogu no ku } \\
\text { kazari. (男セックス道具の鍵飾り)。 }\end{array}$ \\
\hline Jaket & Jaketto (janpaa).ジャケット（ジャンパー）。 \\
\hline Kopi & Koohii. (コーヒー)。 \\
\hline Teh & Ocha. (お茶)。 \\
\hline Coklat & Chokoreeto. チョコレート)。 \\
\hline Patung kayu & Kibori. (木彫り)。 \\
\hline Pembuka botol & Sennuki. (栓抜き)。 \\
\hline Kipas & Sensu. (扇子)。 \\
\hline Mainan & Omocha. (玩具)。 \\
\hline Bodysalt. & Bodii soruto. (ボデイーソルト)。 \\
\hline Sumpit & Hashi. (箬)。 \\
\hline
\end{tabular}

\begin{tabular}{|c|c|c|c|}
\hline $\mathbf{A}$ & Koko; Soko; Asoko wa & Tempat & Desu \\
\hline 1 & $\begin{array}{l}\text { Koko wa } \\
\text { (Di sini) }\end{array}$ & $\begin{array}{l}\text { Toire } \\
\text { (toilet) }\end{array}$ & $\begin{array}{l}\text { Desu } \\
\text { (adalah) }\end{array}$ \\
\hline 2 & $\begin{array}{l}\text { Soko wa } \\
\text { (Di situ) }\end{array}$ & $\begin{array}{l}\text { Resutoran } \\
\text { (Restauran) }\end{array}$ & $\begin{array}{l}\text { Desu } \\
\text { (adalah) }\end{array}$ \\
\hline 3 & $\begin{array}{l}\text { Asoko wa } \\
\text { (Di sana) }\end{array}$ & $\begin{array}{l}\text { Iriguchi } \\
\text { (pintu masuk) }\end{array}$ & $\begin{array}{l}\text { Desu } \\
\text { (adalah) }\end{array}$ \\
\hline B & Subjek wa & $\begin{array}{l}\text { Doko } \\
\text { (Dimanakah) }\end{array}$ & Desu ka (?) \\
\hline 1 & $\begin{array}{l}\text { T:Anata no uchi wa } \\
\text { (Rumahmu) } \\
\text { J:Watashi no Uchi wa } \\
\text { (Rumah saya) }\end{array}$ & $\begin{array}{l}\text { Doko } \\
\text { (Dimanakah) } \\
\text { Denpasar } \\
\text { (Di Denpasar) }\end{array}$ & $\begin{array}{l}\text { Desu ka } \\
\text { Desu } \\
\text { (adalah) }\end{array}$ \\
\hline 2 & $\begin{array}{l}\text { T: Iriguchi wa } \\
\text { (Pintu masuk) } \\
\text { J:Iriguchi wa } \\
\text { (Pintu masuk) } \\
\end{array}$ & $\begin{array}{l}\text { Doko } \\
\text { (Dimanakah) } \\
\text { Asoko } \\
\text { (Di sana) } \\
\end{array}$ & $\begin{array}{l}\text { Desu ka } \\
\text { Desu } \\
\text { (Adalah) }\end{array}$ \\
\hline 3 & $\begin{array}{l}\text { T:Deguchi wa } \\
\text { (Pintu keluar) } \\
\mathrm{J}: \text { Deguchi wa } \\
\text { (Pintu keluar) }\end{array}$ & $\begin{array}{l}\text { Doko } \\
\text { (Dimanakah) } \\
\text { Soko } \\
\text { (Dimanakah) } \\
\end{array}$ & $\begin{array}{l}\text { Desu ka } \\
\text { Desu } \\
\text { (Adalah) }\end{array}$ \\
\hline 4 & $\begin{array}{l}\text { T:Kore wa } \\
\text { (Yang Ini) } \\
\mathrm{J}: \text { Sore wa } \\
\text { (Yang Itu) }\end{array}$ & $\begin{array}{l}\text { Doko no Kuruma } \\
\text { (Mobil buatan dimana) } \\
\text { (Nihon no kuruma) } \\
\text { (Mobil buatan Jepang) }\end{array}$ & $\begin{array}{l}\text { Desu ka } \\
\text { (Adalah) } \\
\text { Desu } \\
\text { (Adalah) }\end{array}$ \\
\hline
\end{tabular}

13) Partikel No artinya Buatan/Asal

\begin{tabular}{|l|l|l|l|}
\hline & \multicolumn{1}{|c|}{ Nama Negara } & \multicolumn{1}{c|}{\begin{tabular}{c}
\multicolumn{1}{c|}{ No } \\
(Buatan)
\end{tabular}} & \multicolumn{1}{|c|}{ Kt Benda Desu } \\
\hline 1 & $\begin{array}{l}\text { Nihon } \\
\text { (Jepang) }\end{array}$ & $\begin{array}{l}\text { No } \\
\text { (Buatan) }\end{array}$ & $\begin{array}{l}\text { Tokei Desu } \\
\text { (Arloji) }\end{array}$ \\
\hline 2 & $\begin{array}{l}\text { Doko } \\
\text { (Di mana) }\end{array}$ & $\begin{array}{l}\text { No } \\
\text { (Buatan) }\end{array}$ & $\begin{array}{l}\text { Tokei Desu ka } \\
\text { (Arloji) }\end{array}$ \\
\hline
\end{tabular}




\begin{tabular}{|c|c|c|c|}
\hline $\mathbf{A}$ & Kochira/Sochira/Achira wa & $\begin{array}{c}\text { Kt Benda penunjuk } \\
\text { tempat/arah }\end{array}$ & Desu \\
\hline 1 & $\begin{array}{l}\text { Kochira wa } \\
\text { (Di sebelah sini/Arah sini) }\end{array}$ & $\begin{array}{l}\text { Omiyage no Mise } \\
\text { (Toko Cindra Mata) }\end{array}$ & $\begin{array}{l}\text { Desu } \\
\text { (Adalah) }\end{array}$ \\
\hline 2 & $\begin{array}{l}\text { Sochira wa } \\
\text { (Di sebelah situ/Arah situ) }\end{array}$ & $\begin{array}{l}\text { Dokutsu no Kaidan } \\
\text { (Tangga Menuju Gowa) }\end{array}$ & $\begin{array}{l}\text { Desu } \\
\text { (Adalah) }\end{array}$ \\
\hline 3 & $\begin{array}{l}\text { Achira wa } \\
\text { (Di sebelah sana'Arah sana) }\end{array}$ & $\begin{array}{l}\text { Bukkyoo no Otera } \\
\text { (Buddhis Tample) }\end{array}$ & $\begin{array}{l}\text { Desu } \\
\text { (Adalah) }\end{array}$ \\
\hline 5 & $\begin{array}{l}\text { Kochira wa } \\
\text { (Di sebelah sini/Arah sini)) }\end{array}$ & $\begin{array}{l}\text { Kita } \\
\text { (Arah Utara) }\end{array}$ & Desu \\
\hline 6 & $\begin{array}{l}\text { Sochira wa } \\
\text { (Di sebelah situ/Arah situ) }\end{array}$ & $\begin{array}{l}\text { Higashi } \\
\text { (Arah Timur) }\end{array}$ & Desu \\
\hline 7 & $\begin{array}{l}\text { Achira wa } \\
\text { (Di sebelah sana/Arah sana) }\end{array}$ & $\begin{array}{l}\text { Minami } \\
\text { (Selatan) }\end{array}$ & Desu \\
\hline 8 & $\begin{array}{l}\text { Achira wa } \\
\text { (Di sebelah/Arah sana) }\end{array}$ & $\begin{array}{l}\text { Nishi } \\
\text { (Barat) }\end{array}$ & Desu \\
\hline $\mathbf{B}$ & $\begin{array}{l}\text { Kt benda } \\
\text { tempat/arah wa }\end{array}$ & $\begin{array}{l}\text { Dochira } \\
\text { (Di sebelah mana/Arah } \\
\text { mana) }\end{array}$ & Desu ka \\
\hline 1 & Higashi wa & Dochira & Desu ka \\
\hline 2 & $\begin{array}{l}\text { Zoo no Dokutsu wa } \\
\text { (Gowa Gajah) }\end{array}$ & $\begin{array}{l}\text { Dochira } \\
\text { (Di sebalah/Di Arah Mana) }\end{array}$ & $\begin{array}{l}\text { Desu ka } \\
\text { (Adalah) }\end{array}$ \\
\hline 3 & $\begin{array}{l}\text { Toire wa } \\
\text { (Toilet) }\end{array}$ & $\begin{array}{l}\text { Dochira } \\
\text { (Arah/ Di sebelah mana) }\end{array}$ & $\begin{array}{l}\text { Desu ka } \\
\text { (Adalah) }\end{array}$ \\
\hline
\end{tabular}

Catatan: Untuk menunjukkan arah Angin maka arah yang ada di depan pembicara disebut Kochira; Arah di sebelah kiri dan kanan pembicara disebut Sochira; Arah di belakang pembicara disebut achira.

14) Pemakaian kata kerja (ikimasu: pergi; Kimasu: datang; Kaerimasu: pulang)

\begin{tabular}{|c|l|l|l|l|}
\hline A & \multicolumn{1}{|c|}{ Subjek wa } & $\begin{array}{c}\text { Keterangan } \\
\text { Waktu } \\
\text { (Itsu: Kapan?) }\end{array}$ & $\begin{array}{l}\text { Keterangan Tempat } \\
\text { E } \\
\text { (Doko e: kemana?) }\end{array}$ & Ikimasu/Kimasu/Kaerimasu. \\
\hline 1 & $\begin{array}{l}\text { Tanaka-san wa } \\
\text { (Tuan Tanaka) }\end{array}$ & $\begin{array}{l}\text { Ashita } \\
\text { (Besok) }\end{array}$ & $\begin{array}{l}\text { Zoo no Dokutsu e } \\
\text { (ke Gowa Gajah) }\end{array}$ & $\begin{array}{l}\text { Ikimasu } \\
\text { (Akan pergi) }\end{array}$ \\
\hline 2 & $\begin{array}{l}\text { Tanaka-san wa } \\
\text { (Tuan Tanaka) }\end{array}$ & $\begin{array}{l}\text { Itsu } \\
\text { (Kapan) }\end{array}$ & $\begin{array}{l}\text { Zoo no Dokutsu e } \\
\text { (Ke Gowa Gajah) }\end{array}$ & $\begin{array}{l}\text { Ikimasu ka } \\
\text { (Akan pergi) }\end{array}$ \\
\hline 3 & $\begin{array}{l}\text { Tanaka-san wa } \\
\text { (Tuan Tanaka) }\end{array}$ & $\begin{array}{l}\text { Ashita } \\
\text { (Besok) }\end{array}$ & $\begin{array}{l}\text { Doko e } \\
\text { (Kemana) }\end{array}$ & $\begin{array}{l}\text { Ikimasu ka } \\
\text { (Akan pergi) }\end{array}$ \\
\hline 4 & $\begin{array}{l}\text { Yoshida-san wa } \\
\text { (Nona Yoshida) }\end{array}$ & $\begin{array}{l}\text { Kinoo } \\
\text { (Kemarin) }\end{array}$ & $\begin{array}{l}\text { Bari e } \\
\text { (Ke Bali) }\end{array}$ & $\begin{array}{l}\text { Kimashita } \\
\text { (Telah datang) }\end{array}$ \\
\hline 5 & $\begin{array}{l}\text { Yoshida-san wa } \\
\text { (Nona Yoshida) }\end{array}$ & $\begin{array}{l}\text { Raishuu } \\
\text { (Minggu depan) })\end{array}$ & $\begin{array}{l}\text { Nihon e } \\
\text { (Ke Jepang) }\end{array}$ & $\begin{array}{l}\text { Kaerimasu } \\
\text { (Akan pulang) }\end{array}$ \\
\hline
\end{tabular}

15) Kata Keterangan 
Pembinaan Kepariwisataan Melalui Pendidikan dan Pelatihan Bahasa Jepang Bagi Pengelola dan Guide Lokal di Desa Wisata Bedulu Kabupaten Gianyar Bali

\begin{tabular}{|l|l|l|l|l|l|l|}
\hline Subjek wa & $\begin{array}{l}\text { Ket. Waktu } \\
\text { (Itsu:Kapan?) }\end{array}$ & $\begin{array}{l}\text { Ket.Penyerta } \\
\text { to (Dare to: } \\
\text { Dengan } \\
\text { Siapa?) }\end{array}$ & $\begin{array}{c}\text { Ket. } \\
\text { Alat }+ \\
\text { de (Nan } \\
\text { de: Naik } \\
\text { Apa?) }\end{array}$ & $\begin{array}{l}\text { Ket.Tempat } \\
\text { e (Doko e: } \\
\text { Kemana) }\end{array}$ & $\begin{array}{l}\text { Ikimasu/Kimasu/ } \\
\text { Kaerimasu }\end{array}$ \\
\hline 1 & $\begin{array}{l}\text { Tanaka } \\
\text { san wa } \\
\text { (Tuan } \\
\text { Tanaka) }\end{array}$ & $\begin{array}{l}\text { Ashita } \\
\text { (Besok) }\end{array}$ & $\begin{array}{l}\text { Okusan to } \\
\text { (dengan istri) }\end{array}$ & $\begin{array}{l}\text { Basu de } \\
\text { (Naik } \\
\text { Bus) }\end{array}$ & $\begin{array}{l}\text { Kintamani e } \\
\text { (Ke } \\
\text { Kintamani) }\end{array}$ & $\begin{array}{l}\text { Ikimasu } \\
\text { (akan pergi) }\end{array}$ \\
\hline 2 & $\begin{array}{l}\text { Tanaka- } \\
\text { san wa }\end{array}$ & Itsu? & Okusan to & Basu de & Kintamani e & Ikimasu ka \\
\hline 3 & $\begin{array}{l}\text { Tanaka- } \\
\text { san } \\
\text { wa }\end{array}$ & Ashita & Dare to ? & Basu de & Kintamani e & Ikimasu ka \\
\hline 4 & $\begin{array}{l}\text { Tanaka- } \\
\text { san wa }\end{array}$ & Ashita & Okusan to & Nan de? & Kintamani e & Ikimasu ka \\
\hline 5 & $\begin{array}{l}\text { Tanaka- } \\
\text { san } \\
\text { wa }\end{array}$ & Ashita & Okusan to & Basu de & Doko e? & Ikimasu ka \\
\hline
\end{tabular}

16) Kata Kerja Transitif (Kata Kerja yang mempunyai objek)

\begin{tabular}{|l|l|l|l|}
\hline \multicolumn{1}{|c|}{ Subjek wa } & \multicolumn{1}{c|}{$\begin{array}{c}\text { Objek wo } \\
\text { (Nani wo: Apa?) }\end{array}$} & \multicolumn{1}{c|}{ Kata Kerja Transitif } \\
\hline 1 & $\begin{array}{l}\text { Tanaka-san wa } \\
\text { (Tuan Tanaka) }\end{array}$ & $\begin{array}{l}\text { Gohan wo } \\
\text { (Nasi) }\end{array}$ & $\begin{array}{l}\text { Tabemasu } \\
\text { (Akan Makan) }\end{array}$ \\
\hline 2 & $\begin{array}{l}\text { Tanaka-san wa } \\
\text { (Tuan Tanaka) }\end{array}$ & $\begin{array}{l}\text { Nani wo } \\
\text { (Apa ?) }\end{array}$ & $\begin{array}{l}\text { Tabemasu ka } \\
\text { (Akan Makan) }\end{array}$ \\
\hline 3 & $\begin{array}{l}\text { Yoshida-san wa } \\
\text { (Nona Yoshida) }\end{array}$ & $\begin{array}{l}\text { Biiru wo } \\
\text { (Bir) }\end{array}$ & $\begin{array}{l}\text { Nomimasu } \\
\text { (Akan Minum) }\end{array}$ \\
\hline 5 & $\begin{array}{l}\text { Yoshida-san wa } \\
\text { (Nona Yoshida) }\end{array}$ & $\begin{array}{l}\text { Nani wo } \\
\text { (Apa?) }\end{array}$ & $\begin{array}{l}\text { Nomimasu ka } \\
\text { (Akan Minum) }\end{array}$ \\
\hline 6 & $\begin{array}{l}\text { Suzuki-san wa } \\
\text { (Tuan Suzuki) }\end{array}$ & $\begin{array}{l}\text { Kibori wo } \\
\text { (Patung Kayu) }\end{array}$ & $\begin{array}{l}\text { Kaimasu } \\
\text { (Akan Membeli) }\end{array}$ \\
\hline 7 & Suzuki-san wa & $\begin{array}{l}\text { Nani wo } \\
\text { (Apa?) }\end{array}$ & $\begin{array}{l}\text { Kaimasu ka } \\
\text { (Akan Membeli) }\end{array}$ \\
\hline
\end{tabular}

17) Keterangan Untuk Kata Kerja Transitif

\begin{tabular}{|l|l|l|l|l|l|}
\hline & \multicolumn{1}{|c|}{ Subjek wa } & $\begin{array}{c}\text { Ket Waktu } \\
\text { (Itsu:Kapan?) }\end{array}$ & $\begin{array}{l}\text { Ket Tempat } \\
\text { de (Doko de: } \\
\text { dimana?) }\end{array}$ & $\begin{array}{l}\text { Objek wo } \\
\text { (Nani wo : } \\
\text { Apa?) }\end{array}$ & $\begin{array}{l}\text { Kata Kerja } \\
\text { Transitif }\end{array}$ \\
\hline 1 & $\begin{array}{l}\text { Suzuki-san wa } \\
\text { (Tuan Suzuki) }\end{array}$ & $\begin{array}{l}\text { Kinoo no Ban } \\
\text { (Kemarin } \\
\text { Malam) }\end{array}$ & $\begin{array}{l}\text { Uluwatu de } \\
\text { (Di Uluwatu) }\end{array}$ & $\begin{array}{l}\text { Kechakku } \\
\text { Dansu wo } \\
\text { (Tarian } \\
\text { Kecak) }\end{array}$ & $\begin{array}{l}\text { Mimashita } \\
\text { (Sudah } \\
\text { menonton) }\end{array}$ \\
\hline 2 & Suzuki-san wa & $\begin{array}{l}\text { Itsu } \\
\text { (Kapan?) }\end{array}$ & Uluwatu de & $\begin{array}{l}\text { Kechakku } \\
\text { dansu wo }\end{array}$ & Mimashita ka \\
\hline 3 & Suzuki-san wa & Kinoo no Ban & Doko de & Kechakku & Mimashita ka \\
\hline
\end{tabular}




\begin{tabular}{|c|c|c|c|c|c|}
\hline & & & (Dimana?) & dansu wo & \\
\hline 4 & Suzuki-san wa & Kinoo no Ban & Uluwatu de & $\begin{array}{l}\text { Nani wo } \\
\text { (Apa?) }\end{array}$ & Mimashita ka \\
\hline 5 & Suzuki-san wa & Kinoo no Ban & Uluwatu de & $\begin{array}{l}\text { Nani wo } \\
\text { (Apa?) }\end{array}$ & $\begin{array}{l}\text { Shimashita } \\
\text { ka } \\
\text { (Melakukan) }\end{array}$ \\
\hline
\end{tabular}

Catatan: partikel wa penanda subjek, partikel de penanda ket tempat, partikel wo penanda objek dari kata kerja transitif, partikel ni (pada), partikel kara (dari), partikel made (sampai) penanda keterangan waktu.

\section{SIMPULAN DAN SARAN}

Desa Bedulu merupakan salah satu desa di Kecamatan Blahbatuh, Kabupaten Gianyar Bali. Desa Bedulu memiliki luas wilayah 457 Hektar. Desa Bedulu memiliki potensi wisata berupa daya tarik wisata Yeh Pulu dan Goa Gajah yang dapat menjadi daya tarik utama bagi wisatawan untuk datang berkunjung. Selain potensi alamnya, Desa Bedulu juga memiliki potensi budaya dan tradisi tersebut masih dilindungi dan dipelihara dengan baik oleh masyarakat Bedulu. Kesiapan Sumber Daya Manusia sangat penting dan merupakan modal dasar keterlibatan masyarakat lokal dalam berbagai aktifitas pariwisata. Berdasarkan karakteristik wisatawan, wisatawan yang datang berkunjung ke Kabupaten Gianyar didominasi oleh Wisatawan Jepang. Dalam berbahasa tidak banyak wisatawan Jepang dapat berkomunikasi dalam Bahasa Inggris. Jikapun wisatawan tersebut ada yang mampu berbahasa Inggris, namun wisatawan akan lebih nyaman menggunakan bahasa mereka sendiri dalam berkomunikasi. Hal ini tentu berimplikasi pada kesiapan Sumber Daya Manusia di Desa Bedulu untuk dapat memahami karakteristik Wisatawan Jepang maupun penguasaan Bahasa Jepang.

Tujuan dari kegiatan ini adalah untuk memberikan pembinaan kepariwisataan melalui pendidikan dan pelatihan Bahasa Jepang bagi pengelola dan pemandu wisata (guide) lokal di Desa Wisata Bedulu sebagai antisipasi menghadapi perkembangan pariwisata daerah tersebut dan perdagangan bebas dunia. Pelaksanaan kegiatan dilakukan di banjar lingkungan Desa Wisata Bedulu, Kabupaten Gianyar Bali. Kegiatan pengabdian kepada masyarakat ini dilakukan dengan cara memberikan pembinaan kepariwisataan berupa pendidikan dan pelatihan yang meliputi: ceramah pariwisata untuk meningkatkan kapasitas masyarakat, praktek langsung Bahasa Jepang yang sangat berguna dan tepat guna kepada masyarakat pengelola dan pemandu wisata (guide) lokal yang ada di Desa Bedulu, Kabupaten Gianyar Bali. Setelah kegiatan ceramah pendidikan dan pelatihan dilaksanakan kemudian dilakukan diskusi dan tanya jawab terkait topik yang dibahas. Pada akhir kegiatan ini diharapkan masyarakat paham dan memiliki pengetahuan dan ketrampilan yang cukup dalam hal pariwisata dan Bahasa Jepang yang berguna untuk profesi yang digelutinya.

Adapun saran yang dapat diberikan, antara lain:

1) Para pengelola dan guide lokal di Desa Bedulu agar berani mempraktekkan Bahasa Jepang yang sudah diajarkan secara langsung untuk meningkatkan kemampuan dan penguasaan serta rasa percaya diri.

2) Membuat brosur dan buku panduan wisata dalam Bahasa Jepang sebagai pegangan bagi pengelola dan guide lokal di Desa Bedulu maupun sebagai bahan informasi bagi wisatawan Jepang. 


\section{UCAPAN TERIMAKASIH}

Kegiatan pengabdian ini dapat terlaksana, tidak terlepas dari dukungan semua pihak, oleh karena itu pada kesempatan ini kami Tim Pengabdi menyampaikan penghargaan dan terima kasih yang sebesar-besarnya kepada Rektor Universitas Udayana; Ketua Lembaga Penelitian dan Pengabdian Kepada Masyarakat Universitas Udayana; Bapak Kepala Desa Bedulu beserta staff pegawai; Para Ketua Pengelola Objek Wisata di Desa Bedulu; Ketua Pengelola Guide Lokal di Objek Wisata Goa Gajah; Para Kepala Lingkungan di Desa Bedulu; Camat Blahbatuh, terimakasih atas segala arahan, informasi, bantuan, serta partisipasinya dalam kegiatan ini.

\section{DAFTAR PUSTAKA}

Anonim (2013). Profil Desa Bedulu, Gianyar-Bali.

Desky, M.A. (2001). Pengantar Bisnis Biro Perjalanan Wisata. Yogyakarta: Adicita Karya Nusa.

Kesrul, M. (2003). Penyelenggaraan Operasi Perjalanan Wisata. Jakarta: PT. Gramedia Widiasarana Indonesia.

Marcini, Marc (1996). Conducting Tours. Delmar Publishers an International Thomson Publishing Company. Muhajir (2005). Menjadi Pemandu Wisata Pemula. Jakarta: PT. Gramedia Widiasarana Indonesia.

Suyitno (2001). Perencanaan Wisata. Yogyakarta: Kanisius.

Yoeti, Oka A. (2001). Tour and Travel Management. Jakarta: PT. Pradnya Paramita 